\title{
Morphological Analyisis of the Fabella in Brazilians
}

\author{
Análisis Morfológico de la Fabela en Brasileños \\ ${ }^{*, * *}$ Julio Guilherme Silva; *,*** Carlos Alberto Araújo Chagas; ${ }^{* * * * *}$ Diego Faria Magalhães Torres; \\ "Lucia Servidio; ${ }^{* * * *}$ Ari Cantuária Vilela \& ${ }^{* * * * *}$ Walker André Chagas
}

SILVA, J. G.; CHAgAS, C. A. A.; TORRES, D. F. M.; SERVIDIO, L.; VILELA, A. C. CHAGAS, W. A. Morphological analyisis of the fabella in Brazilians. Int. J. Morphol., 28(1):105-110, 2010.

SUMMARY: Among the present`s sesamoids in the human body, the fabella can be found in the posterior part of the knee in low incidence. This report is quite controverted in the classic anatomical literature as well as its constitution. Its fixation is on the tendon of the gastrocnemius lateralis, close to its origin, in the posterior part of condilus femuralis lateralis. However, when its occurs, generally induces in the knee the absence of arcuate ligament with the presence of fabellofibular ligament. The prevalence is larger in male individuals. Few studies discuss the histology of the fabella. Some authors suggest that the fabella basically formed by bone tissue and others describe it as a fibrocartilaginous. The aim of this study is to analyze the incidence of the fabella, its histological structure and its association with presence or absence of fabellofibular ligaments through macro and microscopic study. Sixty-two Brazilian's knees were dissected and the fabella was found in two diferent specimens. The tissue had been removed and fixed in $4 \%$ formaldehyde for microscopic evaluation. The fabella is a sesamoid bone that appears on knee in a small frequency in Brazilians. Its presence provokes absence of the arcuate ligament and the presence of the fabellofibular ligament. The histological study demonstrated bone tissues on its constitution without osteoclasts.

KEY WORDS: Sesamoid bones; Morphology; Anatomy; Knee joint.

\section{INTRODUCTION}

The sesamoid bones (1. sesame grain) are structures inside the tendons or in periarticular areas (Debiérre, 1890; Testut, 1927; Goldberg \& Nathan, 1987; DiDio, 2002). They are more frequent in hands and feet fingers near the phalanxes (Goldberg \& Nathan) and the most common is the patella. In humans, we can find about 46 sesamoid bones (Sarin et al., 1999). On knee joint we can find the fabella (1. grano). Its placed inside the tendon of the gastrocnemius lateralis muscle, in posterior part of the condilus femuralis lateralis (Gray, 1977; Miaskiewicz \& Partyka, 1984). Its incidence is controverse for classic anatomic authors. His existence provokes anatomical alterations in the posterior-lateral compartment of the knee. One of the structural changes is the presence of the fabellofibular ligament is the form of short collateral ligament (Kim et al., 1997).

The arcuate and fabellofibular ligaments are

* Gama Filho University UGF, Rio de Janeiro, Brazil.

** Augusto Motta University Center, UNISUAM, Rio de Janeiro, Brazil.

**** Federal Fluminense University, UFF, Niterói, Rio de Janeiro, Brazil.

***** Plínio Leite University Center, UNIPLI, Niterói, Rio de Janeiro, Brazil. structures that contribute with the stabilization of knee joint (Maynard et al., 1996), together with the tendon of the popliteus muscle (Pasque et al., 2003). Besides, the posterior-lateral compartment of the knee still possesses another stabilizer, the popliteo fibular ligament (Ishigooka et al., 2004). Biomechanical studies award those ligaments an important function in the stabilization during the rotatory movements of the knee (Maynard et al.). There are few histological data about fabellar structure (Minowa et al., 2004). Gardner et al. (1970) describes it with fibrocartilaginous constitution. Llorca (1963) states that it is formed by bone tissue and that its prevalence is larger in men.

During the last decades investigation models tried to elucidate the occurrence of sesamoid bones (Sarin et al.) as well as studies of anatomy of the posterior-lateral compartment of the knee, through the dissection and 
images (LaPrade et al., 2000; Munshi et al., 2003; Haims et al., 2000). Based on these evidences including structural changes on knee with the presence of the fabella, and absence of reports about fabella in Brazilians, the aim of this study is analyze the fabela macro and microscopic in Brazilian's.

\section{MATERIAL AND METHOD}

Sixty-four knees of Brazilian corpses were analyzed, in individuals aged between 38 and 78 years old (average of 58.5 years) from three Universities of Rio de Janeiro. All the specimes were fixed in formaldehyde $10 \%$, without defined mortis cause, without traumas, congenital malformations or postural shunting. The same dissection technique were used in all especimes and plans were obeyed, sixty-two knees had been selected. All selected knees had been access by its posterior surface, withdrawal of the skin, subcutaneous screen, until the exposition of the popliteus muscle, muscular settings of the hamstrings and heads of the gastrocnemius lateralis and medialis.

After visual and palpatory evaluation of the lateral head of the gastrocnêmius, during the mesoscopic dissection of the hollow popliteus with magnifying glass of $4 \mathrm{x}$ of increase. The knee capsule was dissected by posterior surface in order to verify the presence of the arcuate ligament and the fabellofibular ligament, observing the relations of the gastrocnemius lateralis tendon with condilus femoralis to confirm fabella`s presence.

The fabella found had been removed, analyzed, and kept in formaldehyde 4\%. All the specimens had been absorbed in paraffin using the histologic routine procedures, and then made series cuts of $20 \mathrm{~mm}$. The histological material had been colored with Hematoxilina-eosine (HE) e Tricomic of Gomori and Masson and analyzed. All materials, microscopic, macroscopic and mesoscopic were archived and photographed.

\section{RESULTS}

Two fabellas were found (01 right / 01 left) corresponding to $3.1 \%$ of the sample. Macroscopically all of the knees with fabella had absence of the arcuate ligament and presence of the fabellofibular ligament (Figs. 1 and 2). Under this ligament it was possible to find the tendon of the popliteus muscle. In these knees other anatomical variations in the posterior part were not found.
The macroscopic analysis of the fabellas revealed in the dorsal part the presence of capsular articulate fibers covering them. In the ventral part an articular facet for the condilus femuralis lateralis was found. In the distal portion of the fabella (Fig.2) was found the point of fixation of the fabellofibular ligament addressed to the head of the fibula.

With elliptic aspect, they presented their largest diameters varying between $1.3 \mathrm{~cm}$ to $1.6 \mathrm{~cm}$ slightly concave in the dorsal part and convex in the ventral part. The borders smoothly irregular projections, structurally made of bone tissues (Fig. 3, 4, 5 and 6). There was a absence of osteoclasts on its constitution in all the materials studied (Figs. 3, 4, 5, 6).

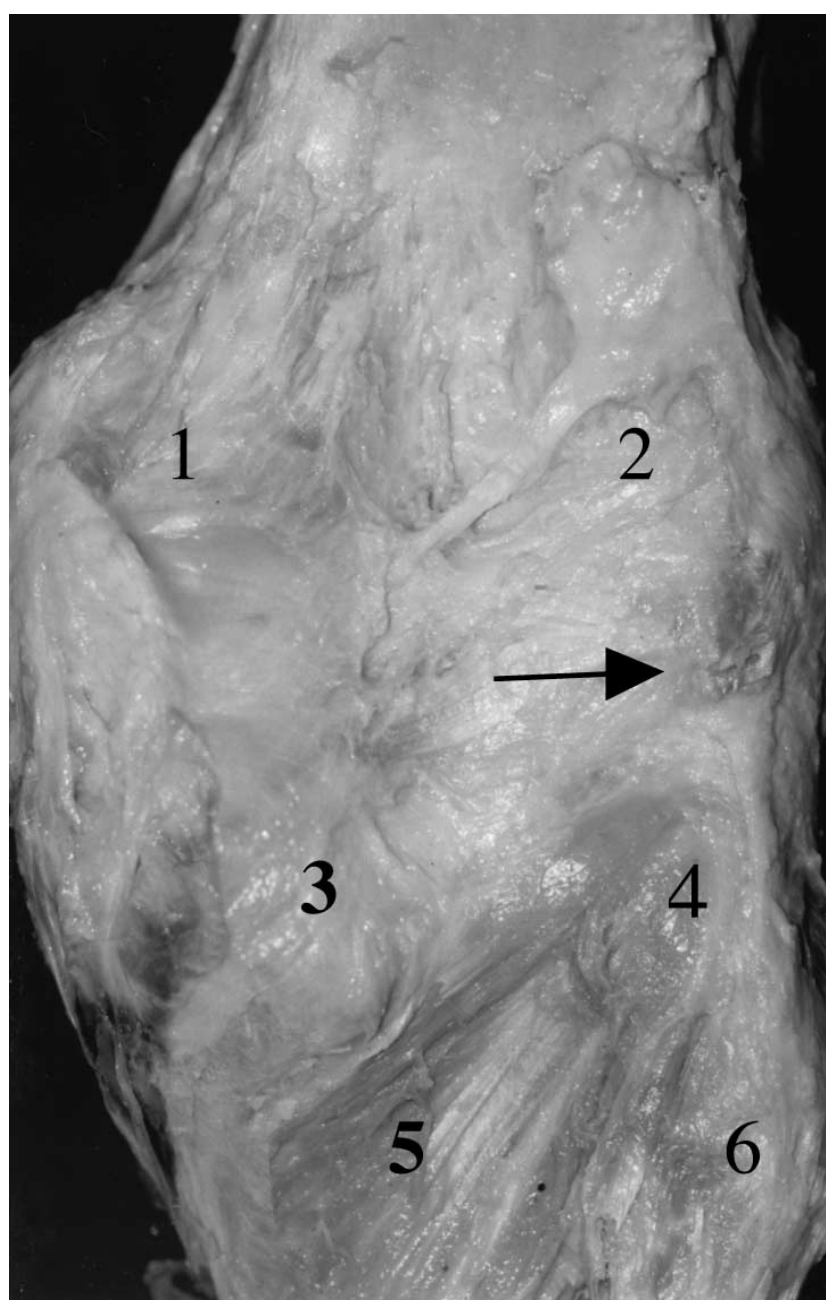

Fig. 1. Posterior view of the knee. 1 and 2. Condilus femuralis lateralis and medialis, respectively; 3. Oblique popliteus ligament. 4. Lig. fabellofibular; 5. Popliteus muscle; 6. Head of the fibula; black arrow - fabella. 


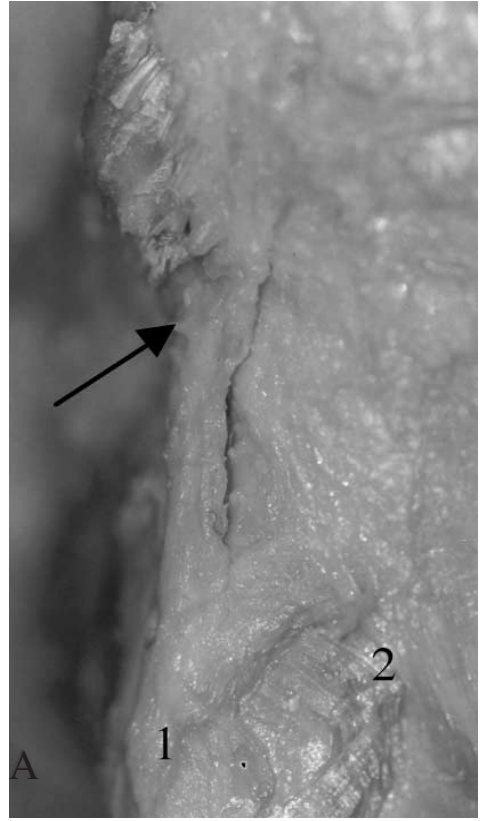

Fig. 2. Lateral, posterior face of knee. Arrow Fabellofibular ligament. 1. Head of the fibula; 2. Popliteo muscle.
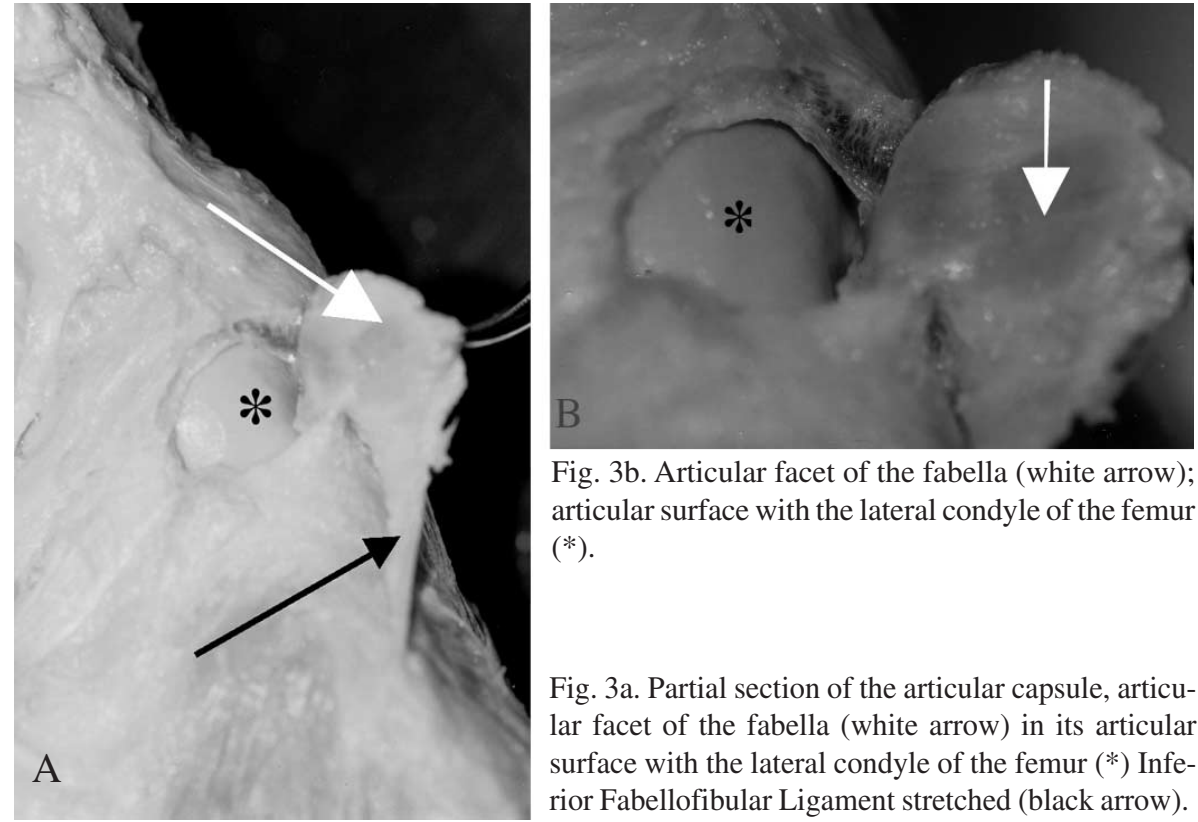

Fig. 3b. Articular facet of the fabella (white arrow); articular surface with the lateral condyle of the femur (*).

Fig. 3a. Partial section of the articular capsule, articular facet of the fabella (white arrow) in its articular surface with the lateral condyle of the femur $(*)$ Inferior Fabellofibular Ligament stretched (black arrow).

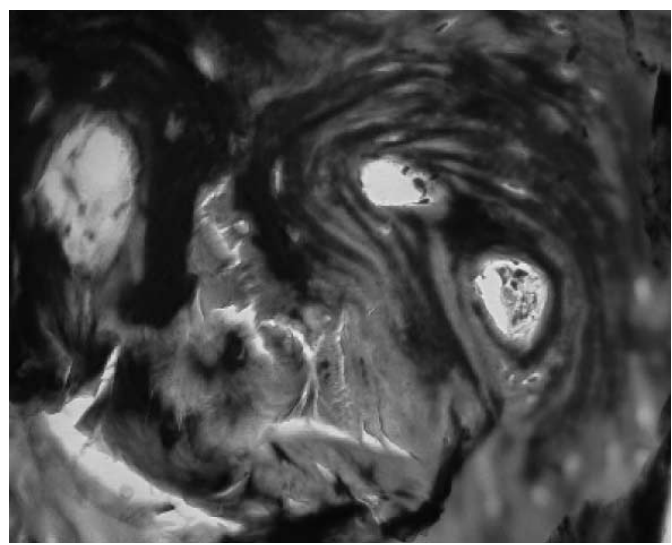

Fig. 5. Cortical with osteon in development and fibers imbeded at the osteal matrix - 400x (Technique of Gomori).

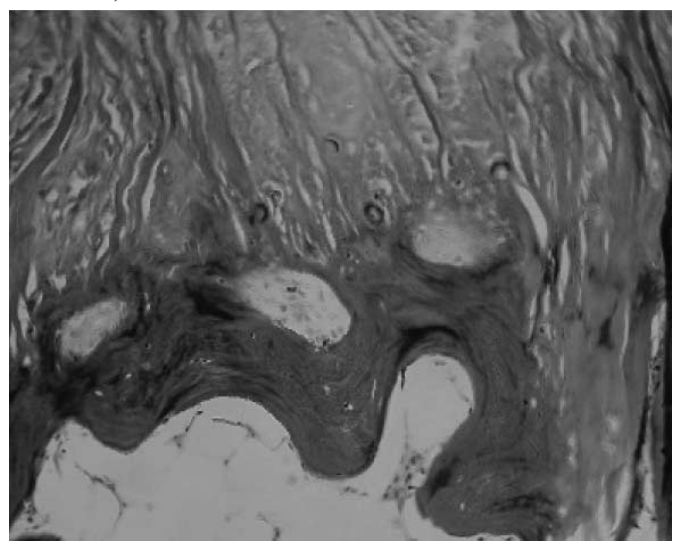

Fig.7. Cortical with ligamentous inserts (fabellofibular ligament) perpendicularly parallel, in permeation with chondrocytes and vision of wide adipose myeloid gaps - 100x (Gomori’s Technique). 


\section{DISCUSSION}

The search for elucidation the mysteries of formation and frequency of the sesamoid bones has been promoting the activity of many researchers (Sarin, 1999). There are two theoretical propositions for the development of those bones, a functional and other phylogenetic (Goldberg \& Nathan; Sarin et al., 1999). The functional theory has a support in the biomechanical aspect, where those bones are described as pulleys, reducing the friction of the tendons and potentiating the muscular handspike (Carey, 1927; Kaplan, 1965; Holladay et al., 1990; Hosseini \& Hogg, 1991). The phylogenetic suggests genetic intrinsic factors developed during the evolutionary process that can be the key for the development of sesamoid bones (Sarin et al.). They appear in the womb period. Initially cartilaginous they can calcify or not after the birth depending on the kind of activity done by the individual, that is, a "biomechanicsembryological" origin (Testut).

The presence of the fabella is also discussed in the literature and associated to clinical facts like as: Fabellar pain syndrome; fabellar chondromalacia (Duncan \& Dahm, 2003) and articular block (Weiner et al., 2007; Larson \& Becker, 1993; Stamatoukou, 2002; Duncan \& Dahm). Due to its location in the posterior-lateral part of the knee, the fabella relations can affect the common fibular nerve (Takebe \& Hirohata, 1981). During decades, the presence of the fabella has been stimulating researchers to correlate its presence with disturbances in the skeletal system mainly with the primary arthrosis on knee (Pritchett, 1984; Sarin et al.). Macroscopically, there is a consensus that the fabella is present in the head of the lateral gastrocnemic although in rare case it was found in the medial gastrocnemic (Gardner et al., 1975; Testut). The fabella is not mentioned in most of the classic texts (Table I). Gardner et al. (1975) mentions besides the description of the fabella, the anatomical variations provoked on knee. Affirms that the fabella provokes absence of the arcuate popliteo ligament. However, new data were studied with the size of the fabella and the thickness of the fabellofibular ligament. Studies show that how biggest is the fabella, more thickest is the fabellofibular ligament (Seebacher et al., 1982). Nowadays serious articles show that not always there is absence of the arcuate popliteo ligament (Table I). According to Minowa et al. of the 29 knees with fabella, 12 had arcuate ligament very defined.

There are a few reports on the fabella's histology. Texts of descriptive anatomy are not quite divergent about its constitution. During the last century, Testut stated that the fabella was fibrocartilaginous. However, Minowa et al. divided the fabella according to the texture and the histology. According to the texture, the exam was done by touching. This way, Minowa et al. characterized the sesamoid as "hard" and "elastic". According to the histological point of view, the fabella was classified about the predominant tissue. Of the 39 fabellas studied, 29 were made of bone tissue; 9 of fibrous tissue and 1 fibrocartilaginous. Following the criterion proposed by Minowa et al., all the fabellas found were "hard", constituted of bone tissue without osteoclasts. The studies and the clinical reports in the posterior-lateral compartment are still "obscure" (Duncan \& Dahm), mainly in the relationship between the fabella and the collateral fibular ligament. The investigation perspectives non-invader can elucidate possible compromisings in the collateral fibular, fabellofibular, popliteofibular ligaments (LaPrade et al.) and consequently to prove the instability in the area (Kim et al.; Haims et al.; Munshi et al.). The absence of osteoclasts told in this text is not mentioned in the world literature. This fact allows to state that the fabella is not susceptible to bone remodelation after its ossification.

Our results allow to state that the fabellas found have the same characteristics than those described in classic texts of macroscopic anatomy which come in the knee joint always

Table I. Registration about fabella, presence of the fabellofibular ligament (FFL) and absent arcuate ligament (AL).

\begin{tabular}{lcccc}
\hline \multicolumn{1}{c}{ Authors/ Year } & $\mathrm{N}^{\mathrm{o}}$ of knees studied / Fabella & $\%$ & FFL & AL \\
\hline Testut* (1927) & $100 / 29$ & 29 & Present & Does not quote \\
Gray* (1977) & Doesn`t related & --- & Does not quote & Absent \\
Orts Llorca* (1962) & $100 / 10$ & 10 & Present & Does not quote \\
Miaskiewicz**(1982) & $188 / 25$ & 13,29 & & Does not quote \\
Terry \& LaPrade*(1996) & $30 /$ does not quote & ---- & Present & Present \\
Sarin* (1999) & $112 / 35$ & 31,25 & Does not quote & Does not quote \\
Moore \& Dalley (2001) & Doesn`t related & $3-5$ & Does not quote & Does not quote \\
Munshi ****(2003) & $7 / 4$ & 57 & Not identified & $50 \%$ lateral \\
Minowa****(2004) & $212 / 182$ & 85,84 & Present & Does mot quote \\
\hline
\end{tabular}

*Anatomical dissection **Radiological study $\quad * * *$ RNM study $\quad * * * *$ Anatomical and histological studies. 
in low frequency (Testut; Gardner et al., 1970; Orts-Llorca, 1952) always including the presence of the fabello-fibular ligament (Gray). It has a hard constitution with bone without osteoclasts cells.
ACKNOWLEDGEMENT. We would like to thank the Histology Laboratory of Gama Filho University by histological photography.

SILVA, J. G.; CHAGAS, C. A. A.; TORRES, D. F. M.; SERVIDIO, L.; VILELA, A. C. CHAGAS, W. A. Análisis morfológico de la fabela en Brasileños. Int. J. Morphol., 28(1):105-110, 2010.

RESUMEN: Entre los huesos sesamoideos que están presentes en el cuerpo humano, la fabela puede encontrarse en la cara posterior de la rodilla. Los reportes de su incidencia son bastante controvertidos en la literatura anatómica clásica, como también su constitución. Hay autores que mencionan a la fabela como tejido óseo, mientras otros la describen como una estructura fibrocartilaginosa. El sitio anatómico de ubicación es el tendón del gastrocnemio lateral, próximo de su origen, en la cara posterior del condilo femoral lateral. La prevalencia es más grande en individuos del sexo masculino. En presencia de este, se observa en rodilla la ausencia del ligamento poplíteo arqueado y la aparición del ligamento fabelo-fibular. Hay pocos trabajos que discuten la anatomía del compartimiento póstero-lateral de la rodilla con la Fabela, así como su constitución. Este trabajo tiene el propósito de analizar la incidencia de la fabela, su estructura histológica, asociándola con la presencia u ausencia de los ligamientos popliteo arqueado y fabelo-fibular a través del estudio macro y microscópico. Fueron disecados sesenta y cuatro cadáveres, sin causa mortis definida. Después fueron disecados. La fabela cuando estuvo presente fue retirada y fijada en formaldehido al $4 \%$ para su evaluación microscópica. De las sesenta y dos rodillas estudiadas dos presentaron fabela. La primera tuvo $1,6 \mathrm{~cm}$ de diámetro, ligeramente cóncava en su cara en contacto con cóndilo femoral lateral, bordes poco irregulares. La segunda tuvo $1,3 \mathrm{~cm}$ de diámetro con las mismas características estructurales. La fabela és un hueso sesamoideo que surge en la rodilla con baja frecuencia. Su aparición se acompañó de la ausencia del ligamento poplíteo-oblicuo y la presencia del ligamento fabelo-fibular. El estudio histológico determinó tejido óseo en su constitución sin osteoclastos.

PALABRAS CLAVE: Huesos sesamoideos; Morfología; Anatomía; Rodilla.

\section{REFERENCES}

Carey, E. J.; Zeit, W., McGrayth, B. F. Study in the dynamics of histogenesis. XII. The regeneration of the patellae of dogs. Am. J. Anat., 40(1):127-58, 1927.

Debiérre, C.H. Traité Élèmentaire d`Anatomie de L'Homme. Paris, Alcan, 1890.

Di Dio, L. J. A. Tratado de Anatomia Sistêmica Aplicada. São Paulo, Atheneu, 2002.

Duncan, W. \& Dahm, D. L. Clinical anatomy of the fabella. Clin. Anat., 16(5):448-9, 2003.

Gardner, E.; Gray, D. J. \& O`Rahilly, R. Anatomia: Estudo regional do corpo humano. $4 \mathrm{a}$ Ed. Rio de Janeiro, Guanabara Koogan, 1970.

Gardner, E.; Gray, D. J. \& O’Rahilly, R. Anatomia. Rio de Janeiro, Guanabara Koogan, 1975.

Gray, H. Gray Anatomia. 29a edição, Rio de Janeiro, Guanabara Koogan, 1977.

Goldeberg, I. \& Nathan, H. Anatomy and pathology of the sesamoid bones. The hand compared to the foot. Int. Orthop., 11(2):141-7, 1987.
Haims, A. H.; Medvecky, M. J.; Pavlovich, Jr., M. \& Katz, L. D. MR imaging of the anatomy of and injuries to the lateral and posterolateral aspects of the knee. Am. J. Roentgenol., 180(3):647-53, 2000.

Holladay, S. B.; Smith, B. J.; Smallwood, J. E. \& Hudson, L. C. Absence of an osseous patella and other observations in Macropodidae stifle. Anat. Rec., 226(1):112-4, 1990.

Hosseini, A. \& Hogg, D. A. Effects of paralysis on skeletal development in the chick embryo I General effects. $J$. Anat., 177:159-68, 1991.

Ishigooka, H.; Sugihara, T.; Shimizu, K.; Aoki, H. \& Hirata, $\mathrm{K}$. Anatomical study of the popliteofibular ligament and surrounding structures. J. Orthop. Sci., 9(1):51-8, 2004.

Kaplan, E. B. Functional and Surgical anatomy of the hand. $2^{\text {nd }}$ Ed. Philadelphia, Lippincott, 1965.

Kim, Y. C.; Chung, I. H.; Yoo, W. K.; Suh, J. S.; Kim, S. J. \& Park, C. Anatomy and magnetic resonance imaging of the posterolateral structures of the knee. Clin. Anat., 10(6):397-404, 1997. 
Larson, J. E. \& Becker, D. A.; Fabellar impingement in total knee arthroplasty. A case report. J. Arthroplasty, 8(1):95$7,1993$.

LaPrade, R. F.; Gilbert, T. J.; Bollom, T. S.; Wentorf, F. \& Chaljub, G. The Magnetic Resonance Imaging Appearance of Individual Structures of the Posterolateral Knee: A Prospective Study of Normal Knees and Knees with Surgically Verified Grade III Injuries. Am. J. Sports Med., 28(2):191-9, 2000.

Llorca, F. O. Anatomia Humana. Barcelona, Editorial Científico Medica, 1952. pp.33-50.

Maynard, M. J.; Deng, X.; Wickiewicz, T. L. \& Warren, R. F. The popliteofibular ligament. Rediscovery of a key element in the posterolateral structures of the knee. Am. J. Sports Med., 24(3):311-6, 1996.

Miaskiewicz, C. \& Partyka, B. Fabella in men of three human races. Folia Morphol., 43(4):369-74, 1984.

Munshi, M.; Pretterklieber, M. L.; Kwak, S.; Antonio, G. E.; Trudell, D. J. Resnick, D. MR Imaging, MR Arthrography, and specimen correlation of the posterolateral corner of the knee: an anatomic study. $A J R$, 180(4):1095-101, 2003.

Minowa, T.; Murakami, G.; Kura, H.; Suzuki, D.; Han, S. H. \& Yamashita, T. Does the fabella contribute to the reinforcement of the posterolateral corner of the knee by inducing the development of associated ligaments? J. Orthop. Sci., 9(1):59-65, 2004.

Orts-Llorca, F. O. Anatomia Humana. $3^{\text {a }}$ edição. Barcelona, Editorial Científico Médica, 1963.

Pasque, C.; Noyes, F. R.; Gibbons M.; Levy, M. \& Grood, E. The role of the popliteofibular ligament and the tendon of popliteus in providing stability in the human knee. $J$. Bone Joint Surg. Br., 85(2):292-8, 2003.

Pritchett, J. W. The incidence of fabellae in osteoarthrosis of the knee. J. Bone Joint Surg. Am., 66(9):1379-80, 1984.

Sarin, V. K.; Erickson, G. M.; Giori, N. J.; Bergman, A. G. \& Carter, D. R. Coincident development of sesamoid bones and clues to their evolution. Anat. Rec., 257(5):174-80, 1999.

Seebacher, J. R.; Inglis, A. E.; Marshall, J. L. \& Warren, R. F. The structure of the posterolateral aspect of the knee. J. Bone Joint Surg. Am., 64(4):536-41,1982.
Stamatoukou, A.; Haslam, P.; Wilton, T. \& Geutjens, G. Locked knee caused by a loose body in the fabellofemoral joint. Am. J. Sports Med., 30(1):128-9, 2002.

Takebe, K. \& Hirohata, K. Peroneal nerve palsy due to fabella. Arch. Orthop. Trauma Surg., 99(2):91-5, 1981.

Testut, L. Traité d`Anatomie Humaine. $8^{\mathrm{a}}$ edição. Paris, Masson, 1927.

Weiner, D.; Macnab, I. \& Turner, M. The Fabella Syndrome. Clin. Orthop. Relat. Res., 126:213-5, 1977.

Correspondece to:

Prof. Julio Guilherme Silva

Rua Filgueiras Lima, 68 apt. 104

CEP 20950-050

Riachuelo, Rio de Janeiro - RJ

BRAZIL

Email: julioguilherme@unisuam.edu.br jglsilva@terra.com.br

Received: 30-07-2009

Accepted: 18-12-2009 